\title{
ČLANCI
}

PETER RADAN, PhD, Professor of Law

Macquarie University, Sydney

Sydney, New South Wels, 2109, Australia

peter.radan@mq.edu.au

originalan naučni rad

UDK: 341.231

primljeno: 17. maj 2017.

prihvaćeno: 11. oktobar 2017.

$323.1(497.5)$

DOI: 10.29362/IST20VEKA.2018.1.RAD.9-34

\section{REPUBLIKA SRPSKA KRAJINA AND THE RIGHT OF PEOPLES TO SELF-DETERMINATION*}

\begin{abstract}
In Part I of this article author details the claims to independent statehood of Croatia and Krajina based upon the right of peoples to self-determination in the context of the emergence of nationalism as a powerful political force in Yugoslavia in the early 1990s. He also details the response of the international community to the crisis which these irreconcilable claims gave rise to. In Part II author explores the reasons why the secession of Croatia succeeded and the secession of Krajina failed. Finally, the ramifications of Croatia's and Krajina's competing claims to statehood for the right of peoples to self-determination are discussed in the Conclusion.
\end{abstract}

KEYWORDS: Republika Srpska Krajina, The break-up of Yugoslavia, War in Croatia 1991-1995, International Law, Self-determination, Secession, Inter-ethnic relations, National Minorities, Serbs in Croatia, Nationalism

\section{Introduction}

On 9 November 1989 the Berlin Wall came down. More than any other, this event of that tumultuous year symbolised the end of the Cold War and ushered in what Allen Buchanan has called 'the age of secession'. 'The usual justification for secessionist demands was the right of peoples to self-determination. One of the means by which this right is realised is by 'the establishment of a sovereign and independent state'. ${ }^{2}$ The critical question for self-determination relates to the meaning of 'peoples'. Only a 'people' has the right to the estab-

\footnotetext{
* BA, LLB, PhD (Syd), Dip Ed (SCAE), FAAL, Professor of Law, Macquarie University. The author thanks Frank Carrigan, Aleksandar Pavković, Andrija Radan, and Ilija Vickovich for their constructive comments on earlier drafts of this article.

${ }^{1}$ Allen Buchanan, „Self-Determination, Secession, and the Rule of Law“, in: The Morality of Nationalism, editors Robert McKim \& Jeff McMahan (Oxford: Oxford University Press, 1997), 301 at 301.

${ }^{2}$ Declaration on Principles of International Law Concerning Friendly Relations and Cooperation Among States in Accordance with the Charter of the United Nations, General Assembly Resolution 2625 (XXV), 24 October 1970.
} 
lishment of a sovereign and independent state. In 1989 the dominant interpretation of 'people' was a territorial one. A 'people' was defined as the population of a territorial unit, be it an internationally recognised state or a colonial entity. This 'classical' theory of self-determination precluded a part any territorial unit from being a 'people'. This understanding of self-determination was generally accepted in Western Europe as being associated with Western understandings of democracy and representative government and took place when the population of a state elected a representative government. It was seen as a continuing process and consistent with the principles of territorial integrity and inviolability of international state borders. ${ }^{3}$

However, a rival theory of self-determination defined a 'people' on the basis of ethnicity and language. A consequence of this 'romantic' theory of selfdetermination was that the population of part of a territorial unit that was ethnically and linguistically different from the remainder of the unit's population was a 'people' and therefore possessed the right to self-determination. This understanding of self-determination was more prevalent in Central and Eastern Europe and was understood as entitling an ethnic or national group to its own nation-state. ${ }^{4}$ Unlike the classical theory of self-determination, it permitted the alteration of international state borders and contemplated acts of secession and irredentism. ${ }^{5}$

The collapse of the Berlin Wall witnessed a renaissance for the romantic theory of self-determination in that it underpinned a flurry of claims to statehood, especially in Eastern Europe. Nowhere was this more vividly illustrated than in the Balkan lands of the south Slavs. Just as the events there leading up to the outbreak of the Great War in 1914 (at times referred to as the Third Balkan War) ${ }^{6}$ led the then great powers to focus intensely on the unresolved 'Eastern Question', the fragmentation of Yugoslavia during the early 1990s led again to the great powers of the day focusing their attention on the 'Eastern Question's' latest iteration. In so doing, the disintegration of Yugoslavia became a laboratory for these great powers to reformulate and enforce a new understanding of the right of peoples to self-determination.

The declarations of independence of the Yugoslav federal republics of Slovenia and Croatia in June 1991 marked the first formal steps towards the secession of these two republics from Yugoslavia. Croatia's declaration of independence prompted the recursive secession ${ }^{7}$ from Croatia of Republika

\footnotetext{
${ }^{3}$ Thomas D. Musgrave, Self-Determination and National Minorities (Oxford: Clarendon Press, 1997), 99.

${ }^{4}$ Ibid., note 3, 102.

${ }^{5}$ Peter Radan, The Break-up of Yugoslavia and International Law (London/New York: Routledge, 2002), 12-23.

${ }^{6}$ Joachim Remak, „1914 - The Third Balkan War: Origins Reconsidered“, Journal of Modern History, vol. 43, no. 3, (1971), 353. However, Glenny refers to the fragmentation of Yugoslavia as ,the third Balkan war": Misha Glenny, The Fall of Yugoslavia, The Third Balkan War, 3rd rev ed. (London: Penguin Books, 1996).

${ }^{7}$ Recursive secession occurs when a secession triggers a secession from within that seceding territory: Aleksandar Pavković, „Recursive Secession of Trapped Minorities: A Comparative
} 
Srpska Krajina (Krajina) in December 1991. Krajina claimed 26.5\% of Croatia's territory that, in most areas, had Serbs as the majority population and contained approximately $65 \%$ of the Serb population of Croatia.

This article will, in Part I, detail the claims to independent statehood of Croatia and Krajina based upon the right of peoples to self-determination in the context of the emergence of nationalism as a powerful political force in Yugoslavia in the early 1990s. In doing so, it will also detail the response of the international community to the crisis which these irreconcilable claims gave rise to. In Part II the reasons why the secession of Croatia succeeded and the secession of Krajina failed will be explored. The ramifications of Croatia's and Krajina's competing claims to statehood for the right of peoples to selfdetermination will be discussed in the Conclusion.

\section{Part I: The Secessions of Croatia and Krajina}

In the post-World War II era, the first significant nationalist movement in Croatia emerged during the so-called 'Croatian Spring' of the late 1960s and early 1970s. ${ }^{9}$ However, following the purge of Croatia's liberal leadership by Tito in early 1972, Croat nationalism remained dormant until the late 1980s. Claims to secession based upon the right of peoples to self-determination only became official republic policy with the electoral victory of Franjo Tuđman and his Croatian Democratic Union (CDU) in Croatia's presidential and parliamentary elections that were held in late April and early May 1990. The CDU won $43 \%$ of the vote, but gained 205 out of 351 seats in Croatia's three chamber parliament - the Sabor. ${ }^{10}$ The CDU election platform, in the words of Tuđman, was centred on the 'struggle to establish an independent, sovereign and democratic Croatia'. Tuđman did not explicitly call for the secession of Croatia, but rather for a new Yugoslav confederation or 'alliance of states'. However, Tuđman's ultimate goal was for Croatia to secede from Yugoslavia. ${ }^{11}$ A crucial part of implementing this platform was reform of Croatia's existing constitution of 1974.

During the election several of Tuđman's campaign statements aroused concerns as to what the process of constitutional meant for Croatia's Serbs. On 24 February 1990, at the CDU's first public rally, he asserted that the genocidal

Study of the Serb Krajina and Abkhazia“, Nationalism and Ethnic Politics, vol. 17, no. 3, (2011), 297 at 297.

${ }^{8}$ Marcus Tanner, Croatia, A Nation Forged in War (New Haven/London: Yale University Press, 1997), 277; Edith Marko-Stöckl, „The Making of Ethnic Insecurity: A Case Study of the Krajina Serbs" Human Security Perspectives, vol. 1, no. 2, (2004), 24 at 25.

${ }^{9}$ Ivo Goldstein, Croatia, A History (London: Hurst \& Co, 1999), 179-83; M. Tanner, op. cit., note 8, 184-202.

${ }^{10}$ Keichi Kubo, „Democratization and Inter-Ethnic Relations in Multiethnic Countries“, Acta Slavica Iaponica, vol. 21, (2004), 181 at 186.

${ }^{11}$ Paul Roe, Ethnic Violence and the Societal Security Dilemma (London/New York: Routledge, 2005), 96-7. 
Ustaša state during World War II was 'an expression of the historical aspirations of the Croat people'. Although this statement represented a sincere belief on the part of Tuđman, it also reflected the significant influence that several pro-Ustaša émigrés had in Croatia as a result of the financial and moral support that both Tuđman and the CDU received from the Croat diaspora. ${ }^{12}$ Subsequently, on 17 March 1990, Tuđman added insult to injury, when he publicly stated that he thanked God that his wife was 'neither a Jew nor a Serb'. ${ }^{3}$

On 28 June 1990, a date of major importance to Serbs as the day for commemorating the legendary Battle of Kosovo in $1389,{ }^{14}$ the process of constitutional reform was formally commenced by the presentation to the Sabor of the first draft of proposed amendments. According to Tuđman the amendments were formulated to make Croatia 'a politically and economically sovereign state'. ${ }^{15}$ The proposed amendments enshrined the Croat literary language as Croatia's official language, adopted a national emblem that was very similar to that used by the Croatian Ustaša state during World War II, and removed the requirement for a two-thirds majority vote in the Sabor on issues relating to national relations within Croatia. ${ }^{16}$ The CDU's referencing of the Ustaša state was of particular sensitivity to the Serbs, who had been its major victims. As Pavlaković points out, 'Tudjman's ambiguous position regarding the rehabilitation of the [former Ustaša state] became a dominant trope of the Krajina Serbs seeking to secede from Croatia and the basis of [Krajina's] efforts at legitimacy'. ${ }^{17}$ Tuđman's failure or reluctance to distance himself and his government from the Ustaša regime had a profound effect on Croatia's Serbs, given that, as Roe notes, 'their families had been subjected to the horrors of the Ustashe'. ${ }^{18}$

The process of constitutional reform culminated in the promulgation of a new constitution on 22 December $1990 .{ }^{19}$ A key provision of the new constitution was Part I (Historical Foundations) in which it was, inter alia, stated:

\footnotetext{
${ }^{12}$ Although Tuđman had fought against the Ustaša forces during World War II, unlike earlier Croat nationalists he was not reticent in seeking their support because ,[he] was not afraid of the [Ustaša] emigrés and was tempted by their big wallets": M. Tanner, op. cit., note 8, 222.

${ }^{13}$ R. Craig Nation, War in the Balkans, 1991-2002, Strategic Studies Institute, 2003, 98.

${ }^{14} 28$ June (Vidovdan for the Serbs) is a date on which a number of historically significant events had occurred, including, the assassination of Archduke Franz Ferdinand in Sarajevo in 1914, the proclamation of The Kingdom of Yugoslavia's first constitution in 1921, and the expulsion of Yugoslavia from Cominform in 1948.

${ }^{15}$ Robert Hayden, Blueprints for a Divided House, The Constitutional Logic of the Yugoslav Conflicts (Ann Arbor: University of Michigan Press), 1999, 47.

${ }^{16}$ R. L. Hislope Jr, „Nationalism, Ethnic Politics, and Democratic Consolidation: A Comparative Study of Croatia, Serbia and Bosnia-Hercegovina“", (Unpublished Doctoral Dissertation, Ohio State University, 1995), 170-171.

${ }^{17}$ Vjeran Pavlaković, „Symbols and the Culture of Memory in Republika Srpska Krajina“, $\mathrm{Na}$ tionalities Papers, vol. 41, no. 6, (2013), 893 at 896.

${ }^{18} \mathrm{P}$. Roe, op. cit., note $12,100$.

${ }^{19}$ Croatia's 1990 Constitution is reproduced in Snežana Trifunovska, Yugoslavia Through Documents, From its Creation to its Dissolution (Dordrecht/Boston/London: Martinus Nijhoff Publishers, 1994), 251.
} 
[T] he Republic of Croatia is hereby established as the national state of the Croat nation and a state of members of other nations and minorities who are its citizens: Serbs, Muslims, Slovenes, Czechs, Slovaks, Italians, Hungarians, Jews and others.

This provision was a significant departure from the 1974 Croatian Constitution which stipulated that Serbs and Croats were constituent nations and equal in status. The 1990 Constitution was directed at the establishment of a Croat nation-state, ${ }^{20}$ and effectively relegated the Serbs, who accounted for $12.2 \%$ of Croatia's population, ${ }^{21}$ to the status of a minority. ${ }^{22}$ As Ignatieff has pointedly observed, 'however much the Croatian nationalists denied it, they did intend to demote the Serbs in Croatia from the status of a founding nationality into an ethnic minority subject to ethnic majority rule'. ${ }^{23}$ The crucial political and legal consequence of the change in status of the Serbs was, as was repeatedly affirmed by Tuđman, that the Serbs, as a minority, had no right to selfdetermination. Article 6 of the Constitution reinforced this denial with its stipulation that the work 'of any political party' whose activities threatened Croatia's 'independence, unity or territorial integrity' constituted a criminal offence.

Article 140 of the Constitution stated that Croatia would remain part of Yugoslavia 'until a new agreement is reached by the Yugoslav republics, or until the Croatian Sabor decides otherwise'. Article 140 went on further to state that if Croatia was in any way endangered, threatened, or disadvantaged within Yugoslavia, including if 'the territorial integrity of the Republic of Croatia [was] infringed', Croatia would make appropriate decisions protecting its interests. Article 140 concluded by asserting that such actions would be justified 'on the basis of the right of self-determination and the sovereignty of the Republic of Croatia'. Secession from Yugoslavia was one such possible action that could be made in such circumstances, given that Article 135 of the Constitution specifically provided for procedures to be followed in the case of secession.

In his speech to the Sabor in relation to the promulgation of the Constitution, Tuđman referred to the occasion as 'a confirmation of the national sovereignty of the Croat nation'. He added that the 'ultimate aim of the Croat nation' was 'for the Republic of Croatia to achieve as soon as possible full, internationally recognised, state sovereignty' and that Croatia was 'against supporting Yugoslavia in the present or some third form'. Rather, Tuđman proposed the

${ }^{20}$ Tomislav Kuzmanović, „Croatia's Constitution: A Blueprint for Democracy in Croatia“, Journal of Croatian Studies, no. 32-33, (1991-1992), 164 at 166.

${ }^{21}$ Ruža Petrović, „The National Composition of Yugoslavia's Population, 1991“, Yugoslav Survey, vol. 33, no. 1, (1992), 3 at 7. For Tuđman the percentage of Croats in Croatia's population qualified Croatia to be called ,nationally homogenous“ nation-state: Franjo Tuđman, Nationalism in Contemporary Europe (New York: Columbia University Press, 1981), 148.

${ }^{22}$ Snežana Trifunovska, „Political and Security Aspects of Minorities in Croatia“, in: Minorities in Europe, Croatia, Estonia and Slovakia, editor Snežana Trifunovska (The Hague: TMC Asser Press, 1999), 21 at 22-4.

${ }^{23}$ Michael Ignatieff, The Warrior's Honor, Ethnic War and the Modern Conscience, Vintage, 1999, 43. 
transformation of Yugoslavia 'into an alliance or perhaps several alliances of sovereign Yugoslav states'. For Tuđman, the justification for this approach was to 'ensure the right of the Croat nation to self-determination'. ${ }^{24}$ Tuđman's speech reflected his long-held views that the Croat nation had the right to selfdetermination pursuant to Yugoslavia's 1974 Constitution, and that this right included a right of secession. ${ }^{25}$

That the process of constitutional reform pursued by Tudman and the CDU would be met with opposition by Croatia's Serbs was clear even before the 1990 elections. Opinion polls conducted prior to the elections confirmed that the majority of Croatia's Serbs strongly opposed any confederalisation of Yugoslavia and rejected the idea of Croatia's secession from Yugoslavia. ${ }^{26}$ The election of Tuđman, the formation of a CDU led government, and the passage of the constitutional reforms impacted directly on ordinary Serbs in Croatia and exacerbated existing tensions between Croatia's Serbs and Croats. As the then United States Ambassador to Yugoslavia Warren Zimmerman reported, the Tuđman government 'presided over serious violations of the rights of Serbs' that saw them 'dismissed from work, required to take loyalty oaths, and subjected to attacks on their homes and property ${ }^{27}$ Furthermore, Croatia began the process of purifying the Croat language so as to clearly differentiate it from the previously common Serbo-Croat/Croato-Serb language used by both Serbs and Croats. ${ }^{28}$

The opposition of Croatia's Serbs to the 1990 Constitution was primarily channeled through the Serbian Democratic Party (SDP) which was formed on 17 February 1990 and led by Dr Jovan Rašković. The SDP's base of support was in rural areas in and around Knin. The SDP was closely affiliated with a party of the same name in Bosnia-Hercegovina and other nationalist parties in Serbia. In the 1990 elections in Croatia the SDP, the only of over thirty parties contesting them that did not have 'Croatia' in its name, gained only 5 out of the 351 seats in the Sabor, all from electorates in and around Knin. ${ }^{29}$ At that election, the majority of Serbs, especially from urban areas, gave their support to the reformed League of Communists of Croatia - Party for Democratic Change (LCC-PDC) and a number of Serbs were elected to the Sabor as members of that party. The LCC-PDC's platform going into the 1990 elections was generally devoid of any form of overt nationalism. The fact that the majority of Serbs

\footnotetext{
${ }^{24}$ Tuđman's speech is reprinted in Izvješća Hrvatskog sabora, br. 15, 22. 12. 1990, with quotations at $8,14,15$.

${ }^{25}$ Franjo Tuđman, Bespuća povijesne zbiljnosti, Rasprava povijesti i filozofija zlosilja (Zagreb: Nakladni zavod Matice Hrvatske, 1990), 454.

${ }^{26}$ Christopher Cviic, „Croatia's Violent Birth“, Current History, vol. 92, no. 577, (November 1993), 370 at 374.

${ }^{27}$ Warren Zimmerman, Origins of a Catastrophe, Yugoslavia and Its Destroyers - America's Last Ambassador Tells What Happened and Why (New York: Times Books, 1996), 75, 132.

${ }^{28}$ Robert D. Greenberg, Language and Identity in the Balkans, Serbo-Croatian and its Disintegration (Oxford: Oxford University Press, 2008), 118-9; P. Roe, op. cit., note 12, 93-4.

${ }^{29}$ Filip Škiljan, „The Organisation and Political Position of Serbs in Croatia“, Serbian Political Thought, vol. 5, no. 4, (2012), 23 at 31.
} 
gave it their support indicates that, given the CDU's electoral triumph, there was no significant Serb nationalism amongst the Serbs at that time and that it was Croats who had been radicalised towards an assertive form of nationalism. ${ }^{30}$ In the wake of the CDU's electoral triumph, the LCC-PDC began to progressively shift towards a more Croat nationalist orientation. This, combined with the subsequent escalation of tensions and eventual military conflict, saw most of their Serb supporters shift their support to the SDP, making it the dominant political party in Krajina. ${ }^{31}$ However, on 18 May 1991, a smaller number of Serbs, mainly located in Zagreb, formed the Serbian People's Party (SPP). The SPP advocated working with the Croatian government as a means of calming nationalist tensions and working towards a civic, rather than nationalist, based Croatian identity. ${ }^{32}$

The initial Serb response to the electoral triumphs of Tuđman and the CDU was a boycott of the Sabor by all of its SDP members, and some of the Serb LCC-PDC members. The boycott was largely in reaction to the displays of Croat nationalism evidenced by the new state symbols that seemingly associated the new government with the Ustaša regime of World War II. ${ }^{33}$

The first major reaction to the initiation of the process of constitutional reform took place in Knin. On 27 June 1990, in anticipation of bringing the proposed constitutional amendments before the Sabor, the Knin municipality heralded the formation of the Association of Municipalities of Northern Dalmatia and Lika, to be initially constituted by six named municipalities in that region plus other municipalities that chose to join it. The Association, to be headquartered in Knin, was to come into existence when two municipalities agreed to become its members. ${ }^{34}$ The formation of the Association was justified on the basis that the proposed amendments to Croatia's Constitution constituted 'a significant violation of the equal rights of the nations and nationalities in Croatia, and in particular of the Serb nation'. The establishment of the Association was said not to be a challenge to the territorial sovereignty of Croatia. Rather, it was said to be based upon the fact that the Serbs were, and had historically been, the majority population in that region, and that the Association was an expression of the national and cultural specificities of that

\footnotetext{
${ }^{30}$ Laura Silber \& Allan Little, Yugoslavia, Death of a Nation (London: Penguin Books, 1996), 95-6.

${ }^{31}$ Nina Caspersen, Contested Nationalism, Serb Elite Rivalry in Croatia and Bosnia in the 1990s (New York: Berghahn Books, 2010), 48-66; Hannes Grandits \& Carolin Leutloff, „Discourses, actors, violence: the organization of war-escalation in the Krajina region of Croatia 1990 1991", in: Potentials of Disorder, editors Jan Koehler \& Christoph Zürcher (Manchester: Manchester University Press, 2003), 23 at 26.

${ }^{32}$ Nikica Barić, „The Establishment and Public Activity of the Serbian People's Party in 1991“, Review of Croatian History, vol. 7, no. 1, (2011), 79.

${ }^{33} \mathrm{H}$. Grandits \& C. Leutloff, op. cit., note 33, 25.

34 „Odluka o osnivanju i konstituiranju Zajednice općina Sjeverne Dalmacije i Like“, 27. jun 1990, u: Uspon i pad „Republike Srpske Krajine“, Dokumenti, urednik Davor Pauković (Zagreb: Centar za politološka istraživanja, 2005), 68.
} 
part of Croatia. ${ }^{35}$ On 1 July 1990 , the Association was formally proclaimed. Its president was Milan Babić, a prominent member of the SDP and mayor of the Knin municipality.

On 25 July 1990, the SDP organised a huge rally of Croatia's Serbs at $\mathrm{Srb}$, a place of symbolic importance to Croatia's Serbs, it being the place where the first uprising against the Ustaša terror took place in July $1941 .^{36}$ The rally formalised the creation of the Serb National Council as the representative body of Croatia's Serbs. Members of the SDP dominated the membership of the Council and, on 31 July 1990, Babić was elected as its president.

The rally at Srb endorsed a Declaration of Sovereignty and Autonomy of the Serb People. ${ }^{37}$ The Declaration asserted the right of Croatia's Serbs to self-determination, including the right of secession, based upon the status of Serbs as a constituent nation of Croatia, with rights to sovereignty equal to that of the Croats. On the basis of this sovereignty the Declaration demanded autonomy for Croatia's Serbs. The extent of that autonomy was dependent upon whether Yugoslavia remained a federation or became a confederation. In the former case, rights to cultural autonomy were asserted. In the latter case, wider rights of autonomy were claimed, including political and territorial autonomy. Finally, the Declaration proclaimed as invalid all changes to Croatia's Constitution that negated the sovereignty of the Serb nation in Croatia or diminished its autonomous rights. This approach to the constitutional changes in Croatia was explained as follows:

The Serb nation in Croatia does not seek what it never had; rather it defends what it earned, together with the Croat nation, at the same time, in the same area and to the same degree. That apart, the Serb nation earned the right, together with the Croat nation and other nations and nationalities, to live in a federal Yugoslavia so as to preserve its unity with all other Serbs on her territory. ${ }^{38}$

Subsequently, the Serb National Council proceeded to organise a plebiscite on autonomy that was held in 23 municipalities in Croatia between 19 August and 2 September 1990 . Of the 756,781 votes cast, 756,549 were in favour of autonomy. ${ }^{39}$ In the wake of the plebiscite the Council issued a Dec-

35 „Zapisnik 1. Sjednice Privremenog predsjedništva Skupštine Zajednice općina Sjeverne Dalmacije i Like“, 3. jul 1990, u: Republika Hrvatska i Domovinski rat 1990-1995. Dokumenti, Knjiga 2, Dokumenti institucija pobunjenih Srba u Republici Hrvatskoj (1990-1991), urednik Mate Rupić (Zagreb: Hrvatski memorijalno-dokumentacijski centar Domovinskog rata, 2007), 33 at 34.

${ }^{36}$ V. Pavlaković, op. cit., note $18,898$.

37 „Deklaracija o suverenosti i autonomiji srpskog naroda“, 25. jul 1990, u: Uspon i pad „Republike Srpske Krajine“, Dokumenti, note 36, 70.

38 „Mišljenje Pravne komisije Srpskog nacionalnog vijeća u svezi nacrta Ustava Republike Hrvatske“, 24. septembar 1990, u: Republika Hrvatska i Domovinski rat, note 37, 72 at 73.

39 „Izvješće Centralne komisije o provođenju izjašnjavanja u Jugoslaviji o autonomiji srpskog naroda u Republici Hrvatskoj“, 30. septembar 1990, u: Republika Hrvatska i Domovinski rat, note 35,83 . 
laration of Serb Autonomy on 30 September $1990 .{ }^{40}$ The Declaration claimed Serb autonomy over territories in Croatia where Serbs lived or which were historically Serb. ${ }^{41}$

During August 1990, the tensions between Croatia and the Serbs in the Knin region escalated with the occurrence of what was commonly referred to as 'the log revolution' (balvan revolucija). The log revolution began with the establishment of roadblocks constructed of logs that made travel between Zagreb and Croatia's Dalmatian coast very difficult. The initial stage of the log revolution created an armed stand-off, but no armed clashes. However, in its second stage armed clashes between Croatian police forces and Serb militia forces occurred in disputed territory at the borders of territory claimed by the Serbs. ${ }^{42}$ Serb militia forces were armed by supplies received from Serbia and by the takeover of armament stockpiles previously under the control of local Yugoslav self-defence units. The actions of the Serbs, aided by support from the Yugoslav People's Army, were in response to what they saw as provocations by the Croatian government. The objective of the Serbs was to assert control over areas in which Serbs constituted a clear majority of the population. ${ }^{43}$

The escalation of political tensions and sporadic fighting in Croatia also saw a change in the leadership of the SDP, which by that time was attracting increasing support from Croatia's Serbs and which was viewed by Tuđman as the representative of Croatia's Serbs. Its first leader, Jovan Rašković, represented the moderate faction within the SDP that stood behind a program based upon the advocacy of democracy, human rights, national equality, and cultural autonomy for Croatia's Serbs within a federal Yugoslavia. ${ }^{44}$

In May 1990 Rašković and Tuđman met on a number of occasions to discuss the issue of the status of Serbs in Croatia. Rašković's position on what Croatia's Serbs would demand in the event of Croatia's secession from Yugoslavia was somewhat ambivalent. He stated that in such an event a referendum would be held in which the Serbs would decide with whom and on whose territory they would live. ${ }^{45}$ The more hardline faction within the SDP, led by Milan Babić, was critical of Rašković's meetings with Tuđman ${ }^{46}$ and his more moderate approach to resolving the political crisis in Croatia. ${ }^{47}$ Furthermore, Babić

${ }^{40}$ „Proglašenje srpske autonomije u Hrvatskoj“, 30. septembar 1990, u: Uspon i pad „Republike Srpske Krajine", note 36, 71.

${ }^{41}$ For a history of the Krajina Serbs see Srđa Trifković, The Krajina Chronicle, A History of Serbs in Croatia, Slavonia and Dalmatia (Chicago: Lord Byron Foundation for Balkan Studies, 2010).

${ }^{42}$ A. Pavković, op. cit., note 7, 312 .

${ }^{43}$ M. Tanner, op. cit., , note 8, 232-4; N. Barić, op. cit., note 33, 77-85.

${ }^{44}$ P. Roe, op. cit., note $12,102-104$.

${ }^{45}$ Susan L. Woodward, Balkan Tragedy, Chaos and Dissolution After the Cold War (Washington: Brookings Institution, 1995), 120.

${ }^{46}$ For a transcript of the Tuđman-Rašković talks and Rašković's account of them see J. Rašković, Luda zemlja (Beograd: Akvarijus, 1990), 291-295, 305-223.

47 „Priopćenje Srpske demokratske stranke kojim se novo vodstvo obračunava s Jovanom Raškovićem i njegovim istomišljenicima“, 19. avgust 1991, u: Republika Hrvatska i Domovinski rat, note 37, 208. 
took a much clearer stance on what should occur if Croatia seceded from Yugoslavia, namely, that the Serb populated areas in Croatia should be annexed by Serbia. These were areas adjacent to Croatia's borders with Bosnia-Hercegovina and Serbia and were, in most cases, formerly part of the historical Military Frontier. They were home to approximately half of Croatia's Serb population. By early 1991, Babić, who was backed by Serbia's president, Slobodan Milošević, ${ }^{48}$ had prevailed in his campaign to supersede Rašković as the effective leader of Croatia's Serbs. ${ }^{49}$

In October 1990, in response to escalating tensions and Serb opposition to the projected constitutional reform in Croatia, the Sabor proposed constitutional amendments that would grant cultural autonomy for Croatia's Serbs. In flatly rejecting these proposals, the Serb National Council asserted that it had the exclusive right to negotiate with the Croatian government on behalf of Croatia's Serbs and that the proposed amendments fell short of what Croatia's Serbs wanted. ${ }^{50}$

On 21 December 1990, in anticipation of the proclamation of the new Croatian Constitution on the following day, municipalities in and around Knin proclaimed the formation of the Serb Autonomous District of Krajina (SAD Krajina). Its formative statute declared SAD Krajina to be the expression of territorial autonomy within Croatia for the purpose of realising the national, cultural, and historical circumstances of its Serb population. The statute also stated that SAD Krajina was to be a territorial unit within Croatia, which in turn was to be within the territorial framework of Yugoslavia. ${ }^{51}$

There is little doubt that the steps taken towards the establishment of the SAD Krajina were to provide a territorial political unit that would, if Croatia declared its independence from Yugoslavia, as many feared she would, separate itself from Croatia and remain in what was left of Yugoslavia. Following the proclamation of SAD Krajina, several Serb majority municipalities in Slavonija, Baranja, and Western Srem established the Serb National Council for Slavonija, Baranja, and Western Srem.

On 20 February 1991 the Slovenian Assembly passed a resolution by which Slovenia disassociated itself from Yugoslavia and other republics. The disassociation, as opposed to secession, was justified 'on the basis of the permanent and inalienable right of self-determination of the Slovene nation, which is one of the basic principles of international law'. ${ }^{52}$ Yugoslavia's Constitutional Court subsequently ruled that this resolution was unconstitu-

\footnotetext{
${ }^{48}$ N. Caspersen, Contested Nationalism, note 33, 57-58.

${ }^{49}$ Ibid., note 33, 51-58, 65-66.

${ }^{50}$ N. Barić, op. cit., note 33, 88-89.

51 „Statut Srpske Oblasti Krajine“, 30 September 1990, u: Uspon i pad „,Republike Srpske Krajine ", note 36,73 .

52 „Resolution of the Assembly of the Republic of Slovenia on the Proposal for the Disunion of the Socialist Federal Republic of Yugoslavia by Mutual Consent", 20 February, 1991, Focus, Special Issue, (Belgrade, 14 January 1992), 14.
} 
tional. ${ }^{53}$ The Court ruled that the provisions on self-determination and secession in the Preamble to Yugoslavia's Constitution of 1974 had no normative status and thus could not be the basis for secession. The only way in which secession could occur would be by legislation passed by the Yugoslav federation through its appropriate and constitutionally sanctioned organs. Furthermore, the Court ruled that the resolution on disassociation amounted to a violation of Yugoslavia's territorial integrity as guaranteed by Article 5 of its 1974 Constitution.

On 21 February 1991, in the wake of the Slovenian Assembly's disassociation resolution, the Sabor passed an act supplementing the constitution that invoked the nullification doctrine in relation to the application of federal laws in Croatia and declared a state of emergency in Croatia. ${ }^{54}$ Yugoslavia's Constitutional Court subsequently ruled that this act was unconstitutional. ${ }^{55}$ Also on 21 February 1991, the Sabor passed a resolution endorsing the process of Croatia's disassociation from Yugoslavia. The resolution was based upon 'the inalienable and inexpendable right of the Croat nation to self-determination, including the right of secession and association with other nations and states'. ${ }^{56}$ The resolution also called for an agreement-based break-up of Yugoslavia into several independent states within the framework of existing republic borders. Yugoslavia's Constitutional Court subsequently declared the Sabor's disassociation resolution unconstitutional on the ground that it effectively amounted to Croatia's secession from Yugoslavia. ${ }^{57}$ The reasoning behind the Court's decision was the same as it had been in relation to Slovenia's disassociation resolution.

With Croatia having, in effect, declared its intention to secede from Yugoslavia, Croatia's Serbs openly declared their intention to disassociate from Croatia if and when Croatia declared its independence from Yugoslavia. Thus, on 26 February 1991 Serbs in Slavonija, Baranja, and Western Srem declared their autonomy. The declaration announced that, through its National Council, they would work towards securing local self-government for the Serbs in that region as well as collaborating with other sections of the Serb nation in Yugoslavia. The declaration further stated that the Serbs in Slavonija, Baranja, and

53 „Odluka o ocenjivanju ustavnosti rezolucije o predlogu za sporazumno razdruživanje Socijalističke Federativne Republike Jugoslavije, 2. oktobar 1991“, Službeni list SFRJ, vol. 47, no. 89, (13. 10. 1991), 1426.

54 „The Constitutional Act Supplementing the Constitutional Act for the Implementation of the Constitution of the Republic of Croatia“, 21 February 1991, in: S. Trifunovska, Yugoslavia Through Documents, note 20, 280.

55 „Mišljenje USJ o suprotnosti odredaba čl. 9A, 9B i 9C ustavnog zakona za provedbu ustava Republike Hrvatske sa ustavom SFRJ, 10. jul 1991“, u: Secesija bivših jugoslovenskih republika u svetlosti odluka Ustavnog suda Jugoslavije, Zbirka dokumenata s uvodnom raspravom, urednik Milovan Buzadżić (Beograd: Službeni list SFRJ, 1994), 86.

${ }^{56}$ „Croatian Resolution on Acceptance of the Process of Disunion“, 21 February 1991, Focus, note $56,17$.

57 „Odluka o ocenjivanju ustavnosti rezolucije o prihvatanju postupka za razdruživanje SFRJ i o mogućem udruživanju u savez suverenih republika, 2. oktobar 1991”, Službeni list SFRJ, god. 47, br. 86, (29. 11. 1991), 1346. 
Western Srem would remain within the Republic of Croatia, but only if the latter remained part of the Yugoslav federal state. The Declaration went on to state that, if Yugoslavia was fragmented into a number of independent states, the Serbs of that region would exercise their autonomy within a Serbian state. ${ }^{58} \mathrm{On}$ 31 March 1991 the National Council resolved to seek annexation of its territory by Serbia. On 23 April 1990 a referendum endorsed a proposal that Slavonija, Baranja, and Western Srem should remain in a single state with Serbia and Montenegro.

Similarly, on 28 February 1991, SAD Krajina passed a resolution on its disassociation from Croatia. The resolution was justified on the basis of 'the internationally recognised right of peoples to self-determination' and on provisions in Yugoslavia's 1974 Constitution prescribing 'the equality of all the Yugoslav nations'. The resolution stipulated that SAD Krajina wished to remain in Yugoslavia and had no objections to 'the right of the Croat people to separate from the Yugoslav state within the bounds of their ethnic space,. ${ }^{59}$ On 18 March 1991, a further resolution was passed that amended SAD Krajina's formative statute that had been adopted on 21 December 1990, by stating that SAD Krajina was now simply a territorial unit within the territorial framework of Yugoslavia. ${ }^{60}$

On 30 April 1991, SAD Krajina resolved to hold a referendum on the issue of whether it should be annexed by Serbia. The referendum question that was approved was: 'Are you in favour of the annexation of SAD Krajina by Serbia? ${ }^{61}$ However, Serbia's president, Slobodan Milošević, immediately announced his rejection of the resolution. The likely reason behind Milošević's decision was that at that time his official policy was of keeping Yugoslavia together. Milošević earlier had attacked the Slovenian and Croatian declarations on sovereignty as unconstitutional and as leading to Yugoslavia's dismemberment. If he had endorsed SAD Krajina's accession to Serbia he would have been accused of breaking up Yugoslavia. Perhaps more importantly, beginning in mid-March 1991, Milošević had a series of meetings with Tuđman in which a territorial carve-up of Bosnia-Hercegovina was discussed, with part of the arrangement including leaving the territory claimed by SAD Krajina to Croatia in exchange for Serbia getting territory that bordered with Serbia centred around the town of Vukovar in eastern Croatia. ${ }^{62}$

In response to Milošević's negative response to their initiative, SAD Krajina, invoking 'the right of peoples to self-determination', hurriedly resolved

58 „Deklaracija o suverenoj autonomiji Srpskog naroda Slavonije, Baranje i Zapadnog Srijema“, 26 February 1991, u: Uspon i pad „,Republike Srpske Krajine“, note 36, 78.

59 „Rezolucija o razdruživanju Republike Hrvatske i Srpske Autonomne Oblasti Krajine“, 28 February 1991, u: Uspon i pad „Republike Srpske Krajine“, note 36, 80.

${ }^{60}$ „Statutarna odluka o promjeni Statuta SAO Krajine“, 18. mart 1991, u: Uspon i pad „, Republike Srpske Krajine“, note 36, 83.

${ }^{61}$ Srđan Radulović, Sudbina Krajine (Beograd: Dan Graf, 1996), 30.

${ }^{62}$ Marko Prelec, „Franjo Tudjman's Croatia and the Balkans“, in: Crises in the Balkans, Views from the Participants, editors Constantine P. Danopoulos \& Kostas G. Messas (Boulder: Westview Press, 1997), 75, 85-86; M. Tanner, op. cit., note 8, 242-243. 
to amend the referendum question to read as follows: 'Are you in favour of the annexation of Krajina to Serbia and for Krajina to remain in Yugoslavia with Serbia, Montenegro and others who wish to preserve Yugoslavia?" ${ }^{63}$ The referendum was held on 12 May 1991 and was carried overwhelmingly. Of the nearly $80 \%$ of eligible voters who voted, $99.8 \%$ responded to the referendum question by voting 'Yes'. 64

On 19 May 1991 Croatia held an independence referendum that resulted in $93.24 \%$ of those voting supporting the creation of a 'sovereign and independent state, which guarantees the cultural autonomy and all civil rights of Serbs and members of other nationalities in Croatia'. ${ }^{65}$ The timing of independence was left to the government to determine in accordance with Article 140 of the Croatian Constitution.

In response to these developments, on 29 May 1991, the Constitutional Law of SAD Krajina was proclaimed. It stipulated that SAD Krajina was constituted for the purpose of realising the national equality, culture, and historic circumstances of Serbs on the historic territory of Dalmatia and the Military Frontier and that it was a part of the Yugoslav federal state. ${ }^{66}$

On 25 June 1991 the Croatian Assembly passed a Constitutional Deci$\operatorname{sion}^{67}$ and a Declaration of Independence. ${ }^{68}$ The Constitutional Decision based Croatia's independence upon the 'inalienable, unconsumable, indivisible and untransferable right of the Croatian nation to self-determination, including the right of disassociation'. In the Declaration of Independence reference was made to the 1974 Yugoslav Constitution granting to 'the Republic of Croatia the right to self-determination including secession'. Both documents referred to Croatia's international borders as being the existing republican borders and those parts of Yugoslavia's international borders relevant to Croatia. The Declaration of Independence also emphasised Croatian claims to independence as deriving from an unbroken period of Croatian statehood going back thirteen centuries and confirmed that Croatia was going to take immediate steps to seek international recognition.

Yugoslavia's Constitutional Court subsequently declared the Constitutional Decision and the Declaration of Independence to be unconstitutional and void. The Court's reasoning referred to, inter alia, violations of provisions of

\footnotetext{
63 „Odluka o raspisivanju referenduma o ulasku SAO Krajine u sastav Republike Srbije“, 30. april 1990, u: Uspon i pad „Republike Srpske Krajine“, note 36, 84.

${ }^{64}$ Republika Hrvatska i Domovinski rat, note 37, 172 at 177.

${ }^{65}$ Budislav Vukas, „The Process of the Establishment of the Independence of the Republic of Croatia from the Perspective of International Law", Review of Croatian History, vol. 7, no. 1, (2011), 11 at 19.

${ }^{66}$ „Ustavni zakon Srpske Autonomne Oblasti Krajine“, Article 1, 29. maj 1991, u: Uspon i pad ",Republike Srpske Krajine“, note 36, 91.

${ }^{67}$ "Constitutional Decision on the Sovereignty and Independence of the Republic of Croatia“, 25 June 1991, in: S. Trifunovska, Yugoslavia Through Documents, note 20, 299.

68 „Declaration on the Establishment of the Sovereign and Independent Republic of Croatia“, 25 June 1991, in: S. Trifunovska, Yugoslavia Through Documents, note 20, 301.
} 
Yugoslavia's 1974 Constitution that: (i) stipulated that Croatia was a part of Yugoslavia (Article 2); (ii) guaranteed Yugoslavia's territorial integrity (Article 5); and (iii) ensured Yugoslavia's international borders which could only be altered by legislation passed by Yugoslavia's Federal Assembly (Article 283). Slovenia's declaration of independence that was proclaimed the day before Croatia's was also declared unconstitutional for similar reasons. ${ }^{69}$

On the same day that Croatia declared its independence, the People's Assembly in Slavonija, Baranja, and Western Srem, invoking 'the right of the Serb people to self-determination', resolved that the people of that region would 'remain in a joint state with other Serbs and Yugoslav peoples that wished to live in a joint Yugoslav state'. The resolution further stated that it would become operative if and when Croatia seceded from Yugoslavia. ${ }^{70}$ On 25 September 1991, on the basis of the referendum that had been held on 23 April 1991, the People's Assembly, in reliance on 'the principle of self-determination', proclaimed the formation of Serbian District of Slavonija, Baranja, and Western Srem (SAD Slavonija, Baranja, and Western Srem), adopted a Constitutional Act that declared the autonomous district a federal unit within Yugoslavia (Article 1) ${ }^{71}$ and installed a government headed by Goran Hadžić. ${ }^{72}$

Following the declarations of independence by Slovenia and Croatia, the European Commission (EC) assumed the management of the crisis in Yugoslavia on behalf of the international community. The EC was divided over how to respond to these declarations. For example, given their historically divergent attitudes towards Yugoslavia and its peoples - in particular the Serbs - France and Germany found themselves at odds with each other on the approach to be taken. France favoured maintaining the territorial integrity of Yugoslavia, ${ }^{73}$ whereas German favoured recognising the two republics. ${ }^{74}$ The ambiguity of the EC position was reflected in an EC Declaration on 5 July 1991, which asserted that, as a result of the secessions of Slovenia and Croatia, 'a new situation [had] arisen'. It also referred to settlement of the crisis on the basis of respect for international law. Particular reference was made to 'the right of peoples to selfdetermination' and the 'territorial integrity of States' ${ }^{75}$ The tenor of this declaration was repeated in the Brioni Accord of 7 July 1991, which also provided

${ }^{69}$ Službeni list SFRJ, god. 46, br. 89, (13. 12. 1991), 1422, 1423 and 1427.

${ }^{70}$ „Odluka o položaju srpskog naroda iz Slavonije, Baranje i Zapadnog Srijema u jugoslavenskoj državnoj zajednici“, 25. jun 1991, u: Uspon i pad „Republike Srpske Krajine“, note 36, 97.

${ }^{71}$ „Ustavni zakon Srpske Oblasti Slavonije, Baranje i Zapadnog Srijema“, 25. septembar 1991, u: Uspon i pad , Republike Srpske Krajine“, note 36, 105.

${ }^{72}$ N. Barić, op. cit., note 33, 108.

${ }^{73}$ Alex Macleod, ,French Policy Toward the War in the Former Yugoslavia: A Bid for International Leadership“, International Journal, no. 52, (1997), 241 at 245-246.

${ }^{74}$ Michael Libal, Limits of Persuasion, Germany and the Yugoslav Crisis, 1991-1992 (Westport Conn: Praeger, 1992); Hans Dietrich Genscher, Rebuilding a House Divided, A Memoir by the Architect of Germany's Reunification (New York: Broadway Books, 1998), 487-521.

75 „EC Declaration on the Situation in Yugoslavia“, 5 July 1991, in: S. Trifunovska, Yugoslavia Through Documents, note 20, 310. 
for a three months' moratorium on implementation of the Slovenian and Croatian declarations of independence. ${ }^{76}$

In the midst of this diplomatic activity a number of municipalities in Croatia with majority Serb populations either resolved, or held referenda, to join SAD Krajina. In western Slavonija, where tensions between local Serbs and the Croatian government had exploded into violence in March $1991,{ }^{77}$ these municipalities, although initially favouring joining SAD Krajina, nevertheless, resolved, on 12 August 1991, to establish a third autonomous district within Croatia, namely, the Serb Autonomous District of Western Slavonija (SAD Western Slavonija).

On 27 August 1991 an EC Declaration on Yugoslavia stated that the EC was determined never to recognise changes to Croatia's frontiers that were brought about by force. This was a significant statement in that it appeared to accept Croatia as a subject of international law. Further, it made clear that the principles of territorial integrity applied not only to international borders, but also to the internal federal borders of an internationally recognised state. The Declaration also established the EC Conference on Yugoslavia as a body to conduct negotiations between interested parties in an effort to resolve the Yugoslav crisis, and an Arbitration Commission that was to advise on issues that were put to it by any of the interested parties. ${ }^{78}$ In due course, former British Foreign Secretary Lord Peter Carrington was appointed to lead the EC Conference on Yugoslavia and French constitutional lawyer Robert Badinter, was appointed to head the Arbitration Commission.

The mandate given to Carrington included two significant conditions. First, none of the six Yugoslav republics would be recognised as an independent state unless there was an overall settlement reached that was acceptable to all six republics. Second, no changes could be made to borders except by peaceful agreement. ${ }^{79}$ This latter point was made explicitly clear in the EC Declaration adopted at the opening of the EC Conference on Yugoslavia on 7 September 1991, that stated that the EC was 'determined never to recognise changes of any borders which have not been brought about by peaceful means and by agreement $^{80}$ (emphasis added.)

With the escalation of military conflict between the fledgling Croatian army and Serb forces in Croatia supported by the Yugoslav People's Army, ${ }^{81}$

76 „Joint Declaration of the EC Troika and the Parties Directly Concerned with the Yugoslav Crisis, the So-Called "Brioni Accord"“", 7 July 1991, in: S. Trifunovska, Yugoslavia Through Documents, note 20,311 at 312 .

${ }^{77}$ Mila Dragojević, „Violence and the Production of Borders in Western Slavonija“, Slavic Review, vol. 75, (2016), 422 at 428-430.

78 „Declaration on Yugoslavia“, 27 August 1991, in: S. Trifunovska, Yugoslavia Through Documents, note 20, 333.

${ }^{79}$ Lord Carrington, ,Turmoil in the Balkans: Developments and Prospects“, RUSI Journal, vol. 137 , no. $5,(1992), 1$ at 1.

${ }^{80}$ „Declaration on the Occasion of the Ceremonial Opening of the Conference on Yugoslavia“, 7 September 1991, in: S. Trifunovska, Yugoslavia Through Documents, note 20, 343.

${ }^{81}$ On the 1991 war in Croatia see: Norman Cigar, „The Serbo-Croatian War, 1991: Political and Military Dimensions“, Journal of Strategic Studies, vol. 16, no. 3, (1993), 297. 
the United Nations (UN) Security Council passed Resolution 713 on 25 September 1991. This resolution imposed 'a general and complete embargo on all deliveries of weapons and military equipment to Yugoslavia', and authorised the Secretary-General of the UN to offer his assistance in seeking to resolve the conflict. ${ }^{82}$ On 8 October 1991, former United States Secretary of State Cyrus Vance was appointed by the Secretary-General as his Personal Envoy for the purposes of assisting the Secretary-General to fulfil his obligations under Resolution $713 .{ }^{83}$ On the same day, following the expiration of the three months' moratorium provided for in the Brioni Accord, Croatia's Sabor formally declared Croatia's secession from Yugoslavia, reiterating the basis of her independence as the 'inalienable right of the Republic of Croatia to selfdetermination, ${ }^{84}$ The Sabor decision was declared unconstitutional by the Yugoslav Constitutional Court in December 1991 on the grounds that Croatia's break with Yugoslavia would be a unilateral, and thus unconstitutional, alteration of Yugoslavia's international borders, and further that Croatia, as a constituent unit of the Yugoslav federation could not act independently in relation to political, economic and other forms of relations with other international states, as this was, by virtue of Yugoslavia's 1974 Constitution, the responsibility of the Yugoslav federal authorities. ${ }^{85}$

On 18 October 1991 the EC Conference on Yugoslavia issued a framework for the peaceful settlement of the Yugoslav crisis in which it referred to the recognition of independence "within the existing borders, unless otherwise agreed, of those republics wishing it ${ }^{96}$ An amended framework issued on 1 November 1991 contained an identical provision. ${ }^{87}$ It was at this stage that Germany, as in 1914, flexed its muscles and used its significant influence within the EC to push through a policy that quickly led to the recognition of both Croatia and Slovenia. Germany justified its approach by reference to the right of peoples (in this case the Slovenes and Croats) to self-determination. ${ }^{88}$ Prior to then Germany had been manoeuvring behind the scenes to secure Western recognition of Slovenia and Croatia and had already given private assurances to Croatia and Slovenia, initially that it would would do everything to ensure recognition and, later, that it was only a matter of time before recognition was forthcoming. ${ }^{89}$ German public opinion, especially that of its managerial elite,

\footnotetext{
${ }^{82}$ Security Council Resolution 713 (1991), 25 September 1991.

${ }^{83}$ Report of the Secretary-General Pursuant to Paragraph 3 of Security Council Resolution 713 (1991), S/23169, 25 October 1991.

84 „Croatian Assembly Declares Secession from Yugoslavia“, 8 October 1991, Focus, note 56, 178.

${ }^{85}$ Službeni list SFRJ, god. 48, br. 12, (21. 2. 1992), 163.

${ }^{86}$ „Peace Conference on Yugoslavia: Arrangements for General Settlement“, Article 1.1(e), 18 October 1991, in: S. Trifunovska, Yugoslavia Through Documents, note 20, 357.

87 „Peace Conference on Yugoslavia: Treaty Provisions for the Convention“, Article 1.1(e), 1 November 1991, in: S. Trifunovska, Yugoslavia Through Documents, note 20, 370.

${ }^{88}$ On Slovenia's independence see P. Radan, The Break-up of Yugoslavia, note 5, 167-174; Ana S. Trbovich, A Legal Geography of Yugoslavia's Disintegration (New York/Oxford: Oxford University Press, 2008), 173-87.

${ }^{89}$ Stjepan Mesić, Kako smo srušili Jugoslaviju, Politički memoari (Zagreb: Globus, 1992), 75.
} 
backed this approach. ${ }^{90}$ The German influence was reflected in the EC's Declaration on the Situation in Yugoslavia of 6 October 1991. This Declaration, which was issued against the background of increased violence in Yugoslavia, said: „The right to self-determination of all peoples of Yugoslavia cannot be exercised in isolation from the interests and rights of ethnic minorities within the individual Republics. These can only be assured through peaceful negotiations for which the Conference on Yugoslavia, including its Arbitration Commission, has been convened".91

Germany then proceeded to announce its intention to recognise Slovenia and Croatia. In doing so Germany ignored advice to the contrary from the administration of President George Bush in the United States, the SecretaryGeneral of the UN, Javier Pérez de Cuéllar, Cyrus Vance, and Lord Carrington. ${ }^{92}$ Nevertheless, Germany's announcement effectively forced the hand of the EC which, at a meeting of EC Foreign Ministers on 16 December 1991, issued a declaration inviting Yugoslavia's republics to submit applications for recognition to the EC by 23 December 1991. Applications for recognition were to be considered by the EC's Arbitration Commission (the Badinter Commission). In its application for recognition a republic had to state whether it: wished to be recognised as an independent state; agreed to accept the commitments of EC guidelines on recognition; agreed to accept obligations respecting human rights and the rights of national or ethnic minorities; and supported the continued efforts of the UN and EC to resolve the Yugoslav crisis. ${ }^{93}$

Accompanying this declaration was a set of guidelines that stipulated certain pre-conditions for recognition. In particular, after specifically confirming 'the principle of self-determination' the guidelines specified the need for 'guarantees for the rights of ethnic and national groups and minorities' as well as 'respect for the inviolability of all frontiers which can only be changed by peaceful means and by common agreement'.94

In anticipation of a plan to submit an application for recognition to the EC, on 19 December 1991 the Assembly of SAD Krajina, the People's Assembly of SAD Slavonija, Baranja, and Western Srem, and the Assembly of SAD Western Slavonija, all met and proclaimed a constitution for a new state of the Republic of Serbian Krajina, constituted by the territories of these three districts. ${ }^{95}$ By

${ }^{90}$ Lenard J. Cohen, Broken Bonds, Yugoslavia's Disintegration and Balkan Politics in Transition, 2nd ed, (Boulder/San Francisko/Oxford: Westview Press, 1995), 236.

91 „EC Declaration on the Situation in Yugoslavia“, 6 October 1991, in: S. Trifunovska, Yugoslavia Through Documents, note 20,351.

${ }^{92}$ Carl C. Hodge, „Botching the Balkans: Germany’s Recognition of Slovenia and Croatia,“ Ethics \& International Affairs, vol. 12, (1998), 1 at 8.

93 „EC Declaration Concerning the Conditions for Recognition of New States“ 16 December 1991, in: S. Trifunovska, Yugoslavia Through Documents, note 20, 431.

94 „EC Guidelines on the Recognition of New States in Eastern Europe and in the Soviet Union“, 16 December 1991, in: The Crisis in Kosovo 1989-1999, editor M. Weller (Cambridge: Documents \& Analysis Publishing Ltd, 1999), 80.

95 „Odluka o proglašenju Ustava Republike Srpske Krajine“, 19. decembar 1991, u: Uspon i pad „,Republike Srpske Krajine“, note 36, 114. 
the terms of its Constitution, Krajina was declared to be 'a nation-state of the Serb nation and the state of all citizens' living in Krajina (Article 1). The Preamble to the Constitution firmly based Krajina's claim to statehood on the right to selfdetermination of its Serb population. However, the Constitution located sovereignty in 'the Serb people of [Krajina] and all citizens who live there' (Article 2). The Constitution also stated that the long-term aspiration of Krajina was a common state for the Serb people of Yugoslavia and that Krajina would transfer part of its authority to the new state upon its creation (Article 123).${ }^{96}$ Krajina's first president was Milan Babić.

On 11 January 1992 the Badinter Commission, having on 29 November 1991 in its Opinion No 1 stated that Yugoslavia was by then 'in the process of dissolution', ${ }^{97}$ issued two further opinions that were critical in relation to the prospects of Krajina gaining recognition. In its Opinion No 2 the Badinter Commission was asked to advise on the following question: „Does the Serbian population in Croatia and Bosnia-Hercegovina, as one of its constituent peoples of Yugoslavia, have the right of self-determination?"

The response of the Badinter Commission was that the right of selfdetermination of Serbs outside Serbia was limited to an entitlement to 'all the rights accorded to minorities and ethnic groups under international law'. However, this right did not extend to the right to modify 'existing frontiers at the time of independence'. ${ }^{98}$ In the context of Croatia this meant the borders of Croatia as they had existed within Yugoslavia at the time of its declaration of independence.

In its Opinion No 3 the Badinter Commission was asked to advise on the following question: „Can the internal boundaries between Croatia and Serbia and between Bosnia-Hercegovina and Serbia be regarded as frontiers in terms of public international law?““

In answering that question the Badinter Commission noted that, in the circumstances of the emergence of new states from the debris of Yugoslavia, which it held was in the process of dissolution, both the external and internal borders of Yugoslavia had to be respected and could not be changed by force. In the case of Yugoslavia's external borders this consequence flowed from various international instruments including the UN Charter and the Helsinki Final Act 1975. In relation to Yugoslavia's internal borders they became protected international borders pursuant to the international law principles of respect for the territorial status quo and the uti possidetis principle, and could only be altered by agreement. ${ }^{99}$ This principle, which had hitherto been applied exclusively to

${ }^{96}$ „Ustav Republike Srpske Krajine“, 19 December 1991, U: Uspon i pad „Republike Srpske Krajine", note $36,115$.

${ }^{97}$ Opinion No 1 of the Arbitration Commission of the Peace Conference on Yugoslavia, 29 November 1991, in: S. Trifunovska, Yugoslavia Through Documents, note 20, 415 at 417.

${ }^{98}$ Opinion No 2 of the Arbitration Commission of the Peace Conference on Yugoslavia, 11 January 1992, in: S. Trifunovska, Yugoslavia Through Documents, note 20, 474.

${ }^{99}$ Opinion No 3 of the Arbitration Commission of the Peace Conference on Yugoslavia, 11 January 1992, in: S. Trifunovska, Yugoslavia Through Documents, note 20, 479. 
maintain former colonial borders in Latin America and Africa when colonies became independent states, was held to be of wider application so that demarcation lines between federal units in an existing state would become international borders in cases of secession or state dissolution. ${ }^{100}$

Upon publication of the EC guidelines on recognition both Croatia and Krajina submitted applications for recognition. However, because Krajina was not a federal republic of Yugoslavia, the EC refused to accept and consider her application. ${ }^{101}$ In relation to Croatia's application the Badinter Commission, after noting that a plebiscite on independence had been held in Croatia, recommended on 11 January 1992, that, with one exception, Croatia met the conditions of recognition. The exception related to Croatia's constitutional law provisions on the rights of national minorities that were, in its opinion, inadequate to meet the EC conditions on recognition. ${ }^{102}$ Nevertheless, Croatia was recognised by the EC on 15 January 1992, on the basis of a hurried assurance obtained from President Tuđman on 13 January 1992, that Croatia's minority Serb population would be granted special autonomous status. ${ }^{103}$ This assurance was deemed sufficient to meet the objection of the Badinter Commission to recognition. On 18 May 1992 the UN Security Council recommended Croatia's admission to the UN. ${ }^{104}$ The UN General Assembly formally admitted Croatia to the UN on 22 May 1992. ${ }^{105}$

\section{Part II: Reasons for the success of Croatia's secession and the failure of Krajina's secession}

The recognition of Croatia's independence by the EC and her admission to the UN marked the beginning of the end in relation of Krajina's aspirations to secede from Croatia. Although Krajina maintained a de facto existence until 1995, there was never any realistic prospect of her independence being recognised. This failure at state creation can be explained as the result of several interrelated reasons.

The most important reason for Krajina's failure to achieve independence was the EC's, and later the UN's, steadfast insistence that Yugoslavia's internal borders were to be the borders of any international states that emerged from her break-up. From a policy perspective, when this policy was concretised by the $\mathrm{EC}$ with the publication of its guidelines on recognition in mid-December 1991, it was justified, as Lord David Owen states, because 'it was considered

\footnotetext{
${ }^{100}$ For a critique of the Badinter Commission opinions see P. Radan, The Break-up of Yugoslavia, note 5, 216-34.

${ }^{101}$ Steven L. Burg \& Paul S. Shoup, The War in Bosnia-Herzegovina, Ethnic Conflict and International Intervention (London: M E Sharpe, 1999), 96.

102 S. Trifunovska, Yugoslavia Through Documents, note 20, 489.

${ }^{103}$ Budislav Vukas, „The Legal Status of Minorities in Croatia“ in: S. Trifunovska, Minorities in Europe, Croatia, Estonia and Slovakia, 39, 52.

${ }^{104}$ Security Council Resolution 753 (1992), 18 May 1992.

${ }^{105}$ General Assembly Resolution 46/238, 22 May 1992.
} 
out of date to draw state borders along ethnic lines', and further because 'boundaries could not be redrawn in view of the large numbers of separate "pockets" where there were ethnic majorities not geographically connected'. ${ }^{106}$ Owen, who was to become Co-Chairman of the Steering Committee of the International Conference on the Former Yugoslavia in August 1992, viewed EC policy here as incomprehensible. French President François Mitterrand also questioned whether 'internal, administrative borders of a country, [should] automatically become internationally recognised borders' ${ }^{107}$ That self-interest and power politics were what underpinned the support of the major powers behind this policy was made readily apparent when, in the final phase of Yugoslavia's disintegration, they readily abandoned it with their recognition of Kosovo, although it was not a republic of either Yugoslavia or Serbia.

The wisdom of the EC's insistence on the sanctity of Yugoslavia's internal republican borders was also questioned by a number of international law scholars. Thus, Hannum suggested that 'an equally compelling case could be made for recognizing the peaceful right to self-determination on the part of trapped minorities within new states'. ${ }^{108}$ Indeed, in October 1990, the Presidency of Yugoslavia suggested such an approach when it proposed amendments to Yugoslavia's constitution that would have entrenched and regulated a right of secession of Yugoslav republics. The proposal stipulated that a republic's secession was to be initiated by means of a referendum of its citizens. A successful referendum required a simple majority of votes in favour of secession. An important qualification on the referendum procedure related to republics with more than one constituent people. In such republics the majority of each people had to vote for secession. However, if a people did not vote for secession, territories in which it was the majority population would remain in Yugoslavia, provided that such territories bordered with the remaining part of Yugoslavia. In effect, this proposal provided for the possible partition of republics following a secession referendum. ${ }^{109}$

A second reason for Krajina's demise was the eventual abandonment of her by Serbia's president, Slobodan Milošević. Krajina's existence and viability was totally dependent upon strategic, military, and economic support from Serbia. However, by 1995, with Serbia in a parlous economic situation as a result of UN-imposed sanctions and with Milošević facing increased opposition within Serbia, the ever pragmatic Milošević, abandoned his strategic goal of uniting Serb territories into one state in order to bring an end to the wars that had rav-

${ }^{106}$ David Owen, Balkan Odyssey (London: Victor Gollancz, 1995), 33.

${ }^{107}$ W. R. Roberts, „The Tragedy that Could Have Been Averted“, in: The South Slav Conflict, History, Ethnicity, and Nationalism, editors Raju G. C. Thomas \& Richard H. Friman (New York/London: Garland Publishing, 1996), 363, 370.

${ }^{108}$ H. Hannum, „Synthesis of Discussions“, in: Peoples and Minorities in International Law, editors Catherine Brölmann, Rene Lefeber \& Marjoleine Zieck (Dordrecht/Boston/London: Martinus Nijhoff, 1993), 333 at 335.

${ }^{109}$ Peter Radan, „Secession and Constitutional Law in the Former Yugoslavia“, University of Tasmania Law Review, vol. 20, (2001), 181 at 200. 
aged much of Yugoslavia since 1991 and to secure his own position of power within Serbia. This meant abandoning any further support for Krajina and her ambitions. ${ }^{110}$ This opened the way for Croatia's military forces, with NATO support, to crush Krajina in Operation Storm in August 1995. By this time, notwithstanding the UN-imposed arms embargo, Croatia's fledgling armed forces of 1991 had, with the tacit approval and support of the EC, especially Germany, and the United States, ${ }^{111}$ been transformed into what O'Shea aptly described as a 'German-equipped and US-trained army"112 against which Krajina's forces were no match and incapable of stemming the expulsion of over 300,000 Serbs from Krajina. ${ }^{113}$ For these displaced Serbs the primary reason for Krajina's demise was Milošević's abandonment of them and the goal of creating a common state for the Serbs of Yugoslavia.

\section{Conclusion}

It is clear that, despite the holding of referenda within defined territorial spaces to establish popular support, both the secession of Croatia from Yugoslavia and Krajina's secession from Croatia were instances of statehood based upon the 'romantic' theory of self-determination. Both Croatia and Krajina asserted their claimed states were national states of their respective Croat and Serb populations.

In recognising Croatia's independence, the EC, and later the $\mathrm{UN}$, acceded to a modified form of the classical theory of self-determination. The EC policy, which was given legal coverage by the opinions of the Badinter Commission, departed from the classical theory by conceding that the right of peoples to self-determination could be exercised by part only of an internationally recognised state which, in the case of a Yugoslavia, was any of its federal republics. In that sense the right to self-determination could be described as consistent with the classical theory of self-determination as it was territorially based and explicitly denied ethnic or national groups within territorial units to selfdetermination in the form of independent statehood. The effectuation of this understanding of self-determination in international law in the form of recognition of Croatia's statehood also trumped Yugoslav domestic law that had declared the secession of Croatia as unconstitutional and therefore illegal.

In practice, the recognition of Croatia's independence and the denial of Krajina's independence amounted to an application of the romantic theory of

\footnotetext{
${ }^{110}$ Milošević's policy about-turn also impacted on Republika Srpska in Bosnia, but not as catastrophically as it did for Krajina. By the Dayton Peace Accords signed in December 1995 Republika Srpska became one of two „entities“ within Bosnia-Hercegovina: P. Radan, The Break-up of Yugoslavia, note 5, 192.

${ }^{111}$ Mile Bjelajac \& Ozren Žunec, „The War in Croatia, 1991-1995“, in: Confronting Yugoslav Controversies, A Scholar's Initiative, editors Charles Ingrao \& Thomas A. Emmert (West Lafayette: Purdue University Press, 2009), 230, 257.

${ }^{112}$ Brendan O'Shea, The Modern Yugoslav Conflict, Perception, Deception and Dishonesty (London/New York: Frank Cass, 2005), 197. On American support for Croatia see D. Binder, „The Role of the United States in the Krajina Issue“, Mediterranean Quarterly, vol. 8, no. 4, (1997) 81.

${ }^{113}$ B. O'Shea, op. cit., note 125, 195-200; A. S. Trbovich, op. cit., note 99, 305-313.
} 
self-determination for the Croat people in Croatia and its denial in the case of Croatia's Serbs. Against this background, Krajina's claim to independence based upon the romantic theory of self-determination could only have succeeded if it had had the support of a state with the military strength and influence to maintain and, if necessary, defend Krajina until such time as her independence was formally recognised. As was pointed out by the Supreme Court of Canada in Reference re: Secession of Quebec, claims to statehood that do not comply with prevailing norms of international law may nevertheless succeed if they are ultimately accepted and recognised by a sufficient number of international states. ${ }^{114}$ This did not, and was never likely to, occur in the case of Krajina. Thus, Krajina's claim was, as suggested by Caspersen, ultimately 'utopian, or perhaps dystopian' notwithstanding that it had 'all the characteristics of a state: a territory, a population, and a government, and several state institutions [that] were created' ${ }^{115}$ The consequence was the expulsion of over 300,000 of Croatia's Serbs when Krajina collapsed in August 1995, an expulsion to which the EC and UN was indifferent and which constituted an abandonment of the EC's commitment to the protection of minorities and human rights which it had emphasised in its conditions for the recognition of former Yugoslav republics in December 1991. In this respect, Ignatieff made the following observation:

It is one of the ironies of the war that the largest single act of ethnic cleansing in the conflict - the Croatian clearance of Krajina, which drove [hundreds of thousands of] Serbs back to Serbia - was committed against a population whom the world held responsible for introducing the term into the language. ${ }^{116}$

That self-interest and power politics were what underpinned the support of the major powers behind the refashioned right of peoples to selfdetermination that meant maintaining the sanctity of internal republic borders as international borders was made readily apparent when, in the final phase of Yugoslavia's disintegration, they readily abandoned the apparent right with their recognition of the secession of Kosovo from Serbia, which was not a republic in either Yugoslavia or Serbia. The result of their response to the disintegration of Yugoslavia was that they carved out their respective spheres of influence, just as their predecessors had done several generations earlier when, at the Congress of Berlin in 1878, they sought, for the first time, to resolve the 'Eastern Question'.

${ }^{114}$ Reference re: Secession of Quebec (1998) 161, Dominion Law Reports (4th) 385 at 432 at 449.

${ }^{115}$ Nina Caspersen, Unrecognized States, The Struggle for Sovereignty in the Modern International System (Cambridge: Polity Press, 2012), 51.

${ }^{116} \mathrm{M}$. Ignatieff, op. cit., note 24, 139. Ignatieff is mistaken in asserting that the term ,ethnic cleansing" was a Serb creation. The Ustaša state used the term during World War II in the context of their genocidal conduct towards the Serbs. For example, in 1941, the Ustaša Minister of Justice, Milovan Žanić, said: „This has to be a country of Croats and nobody else, and the method does not exist which we Ustaša would not use in order to make this country truly Croatian and cleanse it from Serbs, who have threatened us for centuries and would threaten us at the first opportunity“: quoted in Michelle F. Levy, „The Last Bullet for the Last Serb”: The Ustaša Genocide against Serbs: 1941-1945“, Nationalities Papers, vol. 37, no. 6, (2009), 807 at 813. 


\section{REFERENCES}

- Barić, Nikica. „The Establishment and Public Activity of the Serbian People's Party in 1991“. Review of Croatian History, vol. 7, no. 1, (2011), 79-102.

- Binder, D. „The Role of the United States in the Krajina Issue“. Mediterranean Quarterly, vol. 8, no. 4, (1997).

- Bjelajac, Mile \& Ozren Žunec. „The War in Croatia, 1991-1995“. In: Confronting Yugoslav Controversies, A Scholar's Initiative. Editors Charles Ingrao \& Thomas A Emmert, 230-271. West Lafayette: Purdue University Press, 2009.

- Buchanan, Allen. „Self-Determination, Secession, and the Rule of Law“. In: The Morality of Nationalism. Editors Robert McKim \& Jeff McMahan. Oxford: Oxford University Press, 1997.

- Burg Steven L. \& Paul S. Shoup. The War in Bosnia-Herzegovina, Ethnic Conflict and International Intervention. London: M. E. Sharpe, 1999.

- Buzadżić, Milovan, (ed.). Secesija bivših jugoslovenskih republika u svetlosti odluka Ustavnog suda Jugoslavije, Zbirka dokumenata s uvodnom raspravom. Beograd: Službeni list SRJ, 1994.

- Caspersen, Nina. Contested Nationalism, Serb Elite Rivalry in Croatia and Bosnia in the 1990s. New York: Berghahn Books, 2010.

- Caspersen, Nina. Unrecognized States, The Struggle for Sovereignty in the Modern International System. Cambridge: Polity Press, 2012.

- Carrington, Lord. „Turmoil in the Balkans: Developments and Prospects“. RUSI Journal, vol. 137, no. 5, (1992), 1-4.

- Cohen, Lenard J. Broken Bonds, Yugoslavia's Disintegration and Balkan Politics in Transition, 2nd ed. Boulder/San Francisko/Oxford: Westview Press, 1995.

- Cigar, Norman. „The Serbo-Croatian War, 1991: Political and Military Dimensions“. Journal of Strategic Studies, vol. 16, no. 3, (1993), 297-338.

- Cviic, Christopher. „Croatia's Violent Birth“. Current History, vol. 92, no. 577, (November 1993), 370-374.

- Dragojević, Mila. „Violence and the Production of Borders in Western Slavonija“. Slavic Review, vol. 75, (2016), 422-430.

- Genscher, Nahs Dietrich. Rebuilding a House Divided, A Memoir by the Architect of Germany's Reunification. New York: Broadway Books, 1998.

- Glenny, Misha. The Fall of Yugoslavia, The Third Balkan War, 3rd rev ed. London: Penguin Books, 1996.

- Goldstein, Ivo. Croatia, A History. London: Hurst \& Company, 1999.

- Grandits Hannes \& Carolin Leutloff. „Discourses, actors, violence: the organization of war-escalation in the Krajina region of Croatia 1990-1991“. In: Potentials of Disorder. Editors Jan Koehler \& Christoph Zürcher, 23-45. Manchester: Manchester University Press, 2003.

- Greenberg, Robert D. Language and Identity in the Balkans, Serbo-Croatian and its Disintegration. Oxford: Oxford University Press, 2008.

- Hannum, H. „Synthesis of Discussions“. In: Peoples and Minorities in Inter- 
national Law. Editors Catherine Brölmann, Rene Lefeber \& Marjoleine Zieck, 333-335. Dordrecht/Boston/London: Martinus Nijhoff, 1993.

- Hayden, Robert. Blueprints for a Divided House, The Constitutional Logic of the Yugoslav Conflicts. Ann Arbor: University of Michigan Press, 1999.

- Hodge, Carl C. „Botching the Balkans: Germany’s Recognition of Slovenia and Croatia“. Ethics \& International Affairs, vol. 12, (1998), 1-8.

- Hislope, R. L. Jr. Nationalism, Ethnic Politics, and Democratic Consolidation: A Comparative Study of Croatia, Serbia and Bosnia-Hercegovina, Unpublished Doctoral Dissertation, Ohio State University, 1995.

- Ignatieff, Michael. The Warrior's Honor, Ethnic War and the Modern Conscience. Vintage, 1999.

- Kubo, Keichi. „Democratization and Inter-Ethnic Relations in Multiethnic Countries“. Acta Slavica Iaponica, vol. 21, (2004), 181-201.

- Kuzmanović, Tomislav. „Croatia's Constitution: A Blueprint for Democracy in Croatia“. Journal of Croatian Studies, no. 32-33, (1991-1992).

- Levy, Michelle F. „The Last Bullet for the Last Serb“: The Ustaša Genocide against Serbs: 1941-1945'. Nationalities Papers, vol. 37, no. 6, (2009), 807-837.

- Libal, Michael. Limits of Persuasion, Germany and the Yugoslav Crisis, 1991-1992. Westport Conn: Praeger, 1992.

- Macleod, Alex. „French Policy Toward the War in the Former Yugoslavia: A Bid for International Leadership“. International Journal, no. 52, (1997), 243-264.

- Marko-Stöckl, Edith. „The Making of Ethnic Insecurity: A Case Study of the Krajina Serbs“. Human Security Perspectives, vol. 1, no. 2, (2004), 24-33.

- Mesić, Stjepan. Kako smo srušili Jugoslaviju, Politički memoari. Zagreb: Globus, 1992.

- Musgrave, Thomas D. Self-Determination and National Minorities. Oxford: Clarendon Press, 1997.

- Nation, R. Craig. War in the Balkans, 1991-2002. Strategic Studies Institute, 2003.

- O'Shea, Brendan. The Modern Yugoslav Conflict, Perception, Deception and Dishonesty. London/New York: Frank Cass, 2005.

- Owen, David. Balkan Odyssey. London: Victor Gollancz, 1995.

- Pauković, Davor, (ed.). Uspon i pad 'Republike Srpske Krajine', Dokumenti. Zagreb: Centar za politološka istraživanja, 2005.

- Pavković, Aleksandar. „Recursive Secession of Trapped Minorities: A Comparative Study of the Serb Krajina and Abkhazia“. Nationalism and Ethnic Politics, vol. 17, no. 3, (2011), 297-318.

- Pavlaković, Vjeran. „Symbols and the Culture of Memory in Republika Srpska Krajina“. Nationalities Papers , vol. 41, no. 6, (2013), 893-909.

- Petrović, Ruža. 'The National Composition of Yugoslavia's Population, 1991'. Yugoslav Survey, vol. 33, no. 1, (1992), 3-7.

- Prelec, Marko. „Franjo Tudjman's Croatia and the Balkans“. In: Crises in the Balkans, Views from the Participants. Editors Constantine P. Danopoulos \& Kostas G. Messas, 75-92. Boulder: Westview Press, 1997. 
- Radan, Peter. „Secession and Constitutional Law in the Former Yugoslavia“. University of Tasmania Law Review, vol. 20, (2001), 181-200.

- Radan, Peter. The Break-up of Yugoslavia and International Law. London/New York: Routledge, 2002.

- Radulović, Srđan. Sudbina Krajine. Beograd: Dan Graf, 1996.

- Rašković, Jovan. Luda zemlja. Beograd: Akvarijus, 1990.

- Remak, Joachim. „1914 - The Third Balkan War: Origins Reconsidered“. Journal of Modern History, vol. 43, no. 3, (1971), 354-366.

- Roberts, W. R. „The Tragedy that Could Have Been Averted“. In: The South Slav Conflict, History, Ethnicity, and Nationalism. Editors Raju G. C. Thomas \& Richard H. Friman, 363-370. New York/London: Garland Publishing, 1996.

- Roe, Paul. Ethnic Violence and the Societal Security Dilemma. London/New York: Routledge, 2005.

- Rupić, Mate. (ed.). Republika Hrvatska i Domovinski rat 1990-1995. Dokumenti, Knjiga 2, Dokumenti institucija pobunjenih Srba u Republici Hrvatskoj (1990-1991). Zagreb: Hrvatski memorijalno-dokumentacijski centar Domovinskog rata, 2007.

- Silber, Laura \& Allan Little. Yugoslavia, Death of a Nation. London: Penguin Books, 1996.

- Škiljan, Filip. „The Organisation and Political Position of Serbs in Croatia“. Serbian Political Thought, vol. 5, no. 4, (2012), 23-31.

- Tanner, Marcus. Croatia, A Nation Forged in War. New Haven/London: Yale University Press, 1997.

- Trbovich, Ana S. A Legal Geography of Yugoslavia's Disintegration. New York/Oxford: Oxford University Press, 2008.

- Trifkovic, Srđa. The Krajina Chronicle. A History of Serbs in Croatia, Slavonia and Dalmatia. Chicago: Lord Byron Foundation for Balkan Studies, 2010.

- Trifunovska, Snežana. „Political and Security Aspects of Minorities in Croatia“. In: Minorities in Europe, Croatia, Estonia and Slovakia. Editor Snežana Trifunovska, 21-38. The Hague: TMC Asser Press, 1999.

- Trifunovska, Snežana. Yugoslavia Through Documents, From its Creation to its Dissolution. Dordrecht/Boston/London: Martinus Nijhoff Publishers, 1994.

- Tuđman, Franjo. Nationalism in Contemporary Europe. New York: Columbia University Press, 1981.

- Tuđman, Franjo. Bespuća povijesne zbiljnosti, Rasprava povijesti i filozofija zlosilja. Zagreb: Nakladni zavod Matice Hrvatske, 1990.

- Vukas, Budislav. „The Legal Status of Minorities in Croatia“. In: Minorities in Europe, Croatia, Estonia and Slovakia. Editor Snežana Trifunovska, 39-49. The Hague: TMC Asser Press, 1999.

- Vukas, Budislav. „The Process of the Establishment of the Independence of the Republic of Croatia from the Perspective of International Law". Review of Croatian History, vol. 7, no. 1, (2011), 11-35.

-Weller, M. (ed.). The Crisis in Kosovo 1989-1999. Cambridge: Documents \& Analysis Publishing Ltd, 1999. 
- Woodward, Susan L. Balkan Tragedy, Chaos and Dissolution After the Cold War. Washington: Brookings Institution, 1995.

- Zimmerman, Warren. Origins of a Catastrophe, Yugoslavia and its Destroyers - America's last Ambassador tells what happened and why. New York: Times Books, 1996.

PETER RADAN, PhD, Professor of Law

Macquarie University, Sydney

Sydney, New South Wels, Australia

peter.radan@mq.edu.au

\section{REPUBLIKA SRPSKA KRAJINA AND THE RIGHT OF PEOPLES TO SELF-DETERMINATION}

\section{Summary}

The collapse of the Berlin Wall witnessed a renaissance for the romantic theory of self-determination in that it underpinned a flurry of claims to statehood, especially in Eastern Europe. Nowhere was this more vividly illustrated than in the Balkan lands of the South Slavs. The fragmentation of Yugoslavia during the early 1990s led again to the great powers of the day focusing their attention on the 'Eastern Question's' latest iteration. In so doing, the disintegration of Yugoslavia became a laboratory for these great powers to reformulate and enforce a new understanding of the right of peoples to self-determination. The declarations of independence of the Yugoslav federal republics of Slovenia and Croatia in June 1991 marked the first formal steps towards the secession of these two republics from Yugoslavia. Croatia's declaration of independence prompted the recursive secession from Croatia of Republika Srpska Krajina (Krajina) in December 1991. Despite the holding of referenda within defined territorial spaces to establish popular support, both the secession of Croatia from Yugoslavia and Krajina's secession from Croatia were instances of statehood based upon the 'romantic' theory of self-determination. The recognition of Croatia's independence and the denial of Krajina's independence amounted to an application of the romantic theory of self-determination for the Croat people in Croatia and its denial in the case of Croatia's Serbs. Against this background, Krajina's claim to independence based upon the romantic theory of selfdetermination could only have succeeded if it had had the support of a state with the military strength and influence to maintain and, if necessary, defend Krajina until such time as her independence was formally recognised.

KEYWORDS: Republika Srpska Krajina, The break-up of Yugoslavia, War in Croatia 1991-1995, International Law, Self-determination, Secession, Inter-ethnic relations, National Minorities, Serbs in Croatia, Nationalism 